\title{
Video signal level (colour intensity) and effectiveness of electromagnetic infiltration
}

\author{
I. KUBIAK* \\ Military Communication Institute, 22a Warszawska St., 05-130 Zegrze, Poland
}

\begin{abstract}
Nowadays, when we have a strong presence of computers in our everyday lives the protection of electronically processed information using digital machines becomes very important. It is related to accidental formation of electromagnetic fields which distinctive features are intrinsically linked to the nature of processed information. Although many protective measures are taken - from technical to organisational - this phenomenon still poses a great threat. Therefore, methods supporting information protection against the so-called electromagnetic infiltration are still being developed. In addition, these methods would support security of data processing and perhaps replace some of the currently used solutions characterised by high costs of implementation, or a small degree of ergonomics. Conducted research deals both with an analogue VGA and digital DVI standards. The article presents the results of the research concerning possibilities of manipulating the level of video signal (black colour intensity) and its influence on the quality of displayed images, that is, on the effectiveness of electromagnetic infiltration.
\end{abstract}

Key words: colour intensity, information protection, electromagnetic infiltration process.

\section{Introduction}

VGA and DVI are video standards currently used in nonpublic information systems. These standards are the object of the research on solutions that effectively protect processed graphical data. Most frequently, the only solutions used for electromagnetic data protection are those design-related which decrease the level of unwanted emissions at a source, as well as organisational solutions which limit physical access to processed information.

Design-related solutions may affect the appearance and ergonomics of a device. Also, the costs of such solutions are great. Therefore, there is a continuous search for solutions that would reduce the costs of information protection. Conversions of commercial devices and the so-called area zoning are proven and used solutions. The use of programme-based solutions in form of specially designed character shapes of fonts seems to be a new approach [1-21]. The possibilities of using them for information protection against electromagnetic infiltration are presented, e.g. in [6] and [7].

An important issue as regards all analyses on prevention of electromagnetic infiltration are the changes in characteristic features of video signals and the possibilities of changing the levels of video signals between the computer central unit and display device, which is the monitor of the computer. However, we do not speak here of a hardware-related solution such as Filtering-Shaping Unit which was broadly described in [2]. This unit introduces spectral limitations of useful signals through smoothing the slopes of increasing and decreasing information signal impulses. The characters displayed on the monitor become then blurred and indistinct, and in the case of DVI there are spurious pixels which can be seen in form of impairments of the displayed image. Another problem we discuss is reduction of intensiveness of colours displayed on the monitor which affects the decrease in the differences between peak and bottom values of voltage of the impulses responsible for displaying an appropriate graphical sign. This applies in particular to written text, writing of which may be necessitated by the grey level. The same can be achieved by retaining text colour intensity at $100 \%$ and increasing the background intensity of black colour. Relevant research was conducted and the results are present below.

\section{Influence of background colour change on text legibility}

When working on a text it is important that it retains its legibility. This means all of typographic parameters (character size and type, its colour, background colour) should be selected in such way that the reader can read the text quickly and without any problems, ensuring thus electromagnetic security against infiltration. Security is understood as a lack of possibilities to display graphical signs from registered signals of compromising emanations.

The appearance of computers and their common usage as typical typing machines caused higher risk related to the loss of information stored on them, such as texts. A series of studies is conducted to propose solutions that make it possible to protect data against their non-invasive acquisition. The studies, among other things, consist in using specially designed fonts and changing intensity of colours of fonts and their background. The influence of these solutions on text legibility was frequently examined both for usage of special fonts and various colours related to the intensity of black

*e-mail: i.kubiak@wil.waw.pl 
colour. The effectiveness of special fonts was confirmed, e.g. in [7]. The attempts to display characters and ciphers using relevant methods for image processing become ineffective, and searching for an appropriate sign using sign correlation method results in making many false decisions. Sign Error Rate is considerably higher than for traditional fonts.

Another important element affecting the level of information protection is the intensity of the colour in which a text is written and its background. This is directly linked to the voltage values of VGA video signal which is widely used in non-public IT systems. The studies in the legibility of a text written on a background other than white were conducted by Professor Bror Zachrisson from Stockholm. He was one of the first scientists who studied the issues regarding text legibility, reading speed, reading comfort of both a text displayed on the monitor and a printed text. He examined, e.g. differences in the legibility of Antiqua and non-serif fonts, the relation between legibility and character size, whether the font from a book that was read is perpetuated in the memory, etc. Zachrisson's findings show that at different stages of human development different elements, such as letter structure, its size, print and paper colour affect the speed of reading information. He also noticed that old books with yellowed pages are read slightly faster than those which have just been printed on white paper. We should surmise then that reducing the contrast between the text and the background should improve legibility (Fig. 1) and, at the same time, reduce the voltage of impulses.

a) Dane zapisane fontami bezpiecznymi za każdym razem były nieczytelne. Metoda wzrokowa okazała się nieskuteczna co jest zjawiskiem pozytywnym w odniesieniu do fontów bezpiecznych. Autor zaproponował podeprzeć analizę wzrokową analizą decyzyjną wspomaganą komputerowo. W tym celu wykorzystał wartości progowe współczynnika dwuwymiarowej korelacji znakowej RZpr, dla których określono wymaganą liczbę poprawnie odtworzonych znaków na poziomie ufności równym $90 \%$. Dla tak przyjętych parametrów analizy, autor przeprowadził stosowne obliczenia wartości Znakowej Stopy Błędów (ZSB) dla obrazów zawierających znaki fontów tradycyjnych i fontów bezpiecznych

b) Dane zapisane fontami bezpiecznymi za każdym razem były nieczytelne Metoda wzrokowa okazała się nieskuteczna co jest zjawiskiem pozytywnym w odniesieniu do fontów bezpiecznych. Autor zaproponował podeprzeć analizę wzrokową analizą decyzyjną wspomaganą komputerowo. W tym celu wykorzystał wartości progowe współczynnika dwuwymiarowej korelacji znakowej RZpr, dla których określono wymaganą liczbę poprawnie odtworzonych znaków na poziomie ufności równym $90 \%$. Dla tak przyjętych parametrów analizy, autor przeprowadził stosowne obliczenia wartości Znakowej Stopy Błędów (ZSB) dla obrazów zawierających znaki fontów tradycyjnych i fontów bezpiecznych

c) Dane zapisane fontami bezpiecznymi za każdym razem były nieczytelne. Metoda wzrokowa okazała się nieskuteczna co jest zjawiskiem pozytywnym w odniesieniu do fontów bezpiecznych. Autor zaproponował podeprzeć analizę wzrokową analizą decyzyjną wspomaganą komputerowo. W tym celu wykorzystał wartości progowe współczynnika dwuwymiarowej korelacji znakowej RZpr, dla których określono wymaganą liczbę poprawnie odtworzonych znaków na poziomie ufności równym $90 \%$. Dla tak przyjętych parametrów analizy, autor przeprowadził stosowne obliczenia wartości Znakowej Stopy Błędów (ZSB) dla obrazów zawierających znaki fontów tradycyjnych i fontów bezpiecznych

Fig. 1. Exemplary images of texts written with font "Arial" on the background with different intensity degree of black colour: a) $0 \%$, b) $20 \%$, c) $30 \%$

\section{VGA and DVI signal level}

VGA and DVI are the standards used in processing of graphical data. The first is an analogue standard still commonly used in non-public IT systems. This standard is not sensitive to the changes of basic parameters. Important parameters are signal level and impulse duration times, their increase and decrease times, which was confirmed in [3]. DVI is a digital standard, it is more sensitive and its decision systems require retaining basic parameters. Slight changes to them cause spurious pixels to be displayed or "breaking" of synchronisation resulting in a total lack of image display. Therefore, we should use other solutions introducing a decrease in signal levels which are sources of compromising emanations. One of such solutions may be a change to intensity of the colour in which the text displayed on the monitor is processed. In stead of using black colour we may try to use different grey levels which, at the same time, will allow for unproblematic reading of created texts.

Consider, however, coding principle of grey level for two graphical standards in question and the fact whether the change in intensity of black colour really affects the electric signal level. As we said, VGA is an analogue standard. The change in intensity of black colour observed on the monitor as different grey level is linked to the change to electric signal voltage (Figs. 2 and 3).

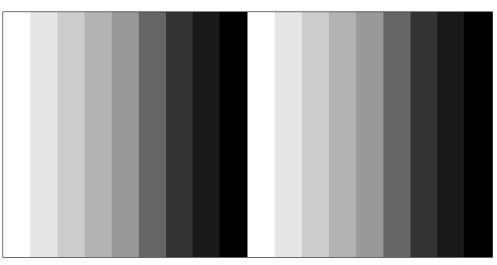

Fig. 2. Image displayed on the monitor while testing parameters of information signals in form of lines in grey level (resolution: $800 \times 600$, refreshing frequency: $60 \mathrm{~Hz}$ )

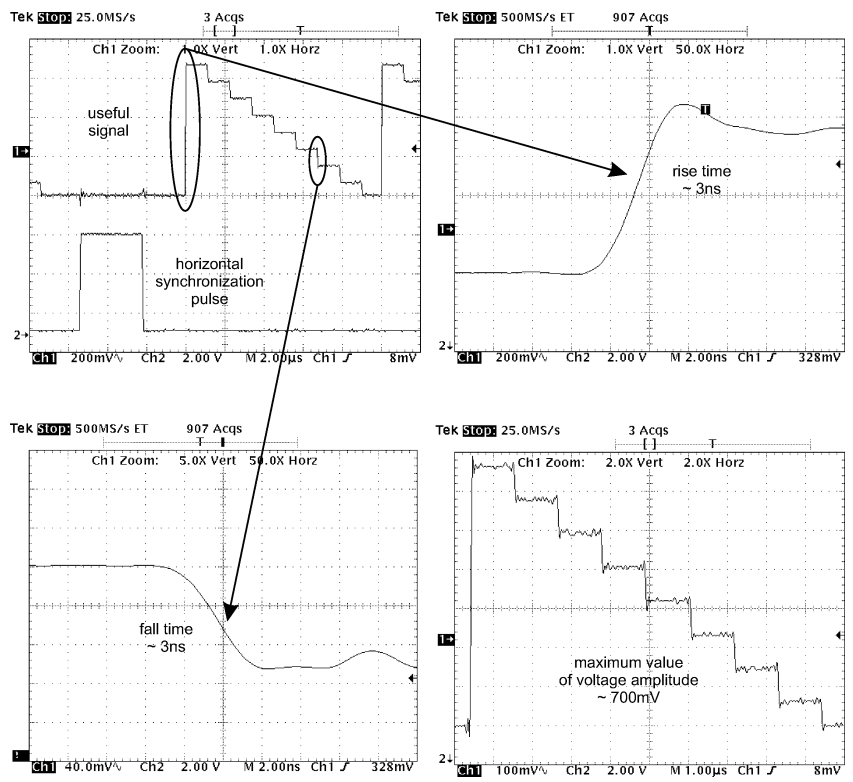

Fig. 3. Time parameters of a useful signal generated by a video card for displayed image presented in Fig. 2 - dependence of grey level on electric signal level 
The time parameters of a useful signal impulse remain unchanged. Pixels of the same colour that occur next to one another in a horizontal line (Fig. 4) are represented in form of an electric impulse with an appropriate duration time and voltage amplitude value. Basic colour is impulse voltage amplitude which equals approx. $700 \mathrm{mV}$ (Fig. 5).

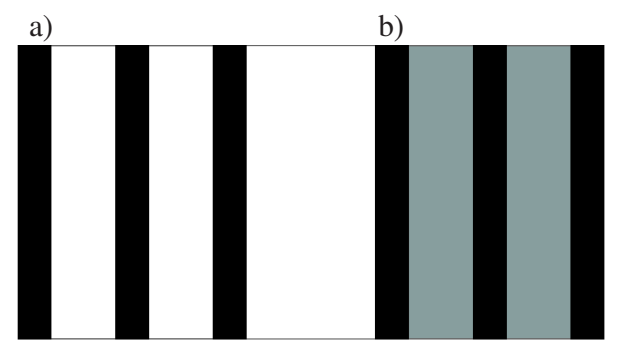

Fig. 4. Image displayed on the monitor while testing time parameters of VGA signals: a) white colour (maximal amplitude voltage),

b) grey colour $50 \%$ ( $1 / 2$ of maximal amplitude voltage)

a)
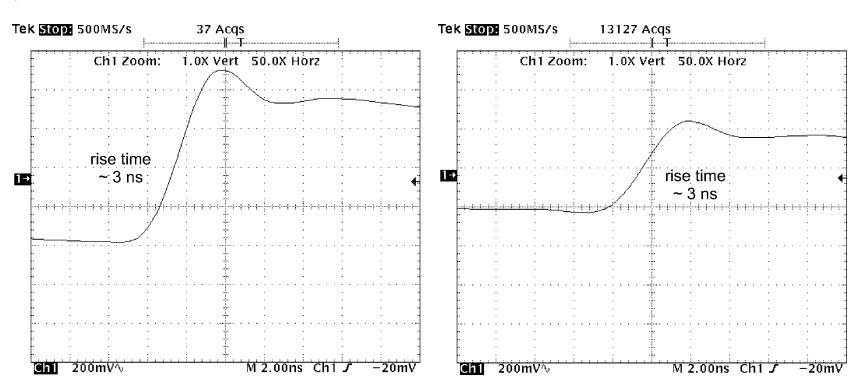

b)
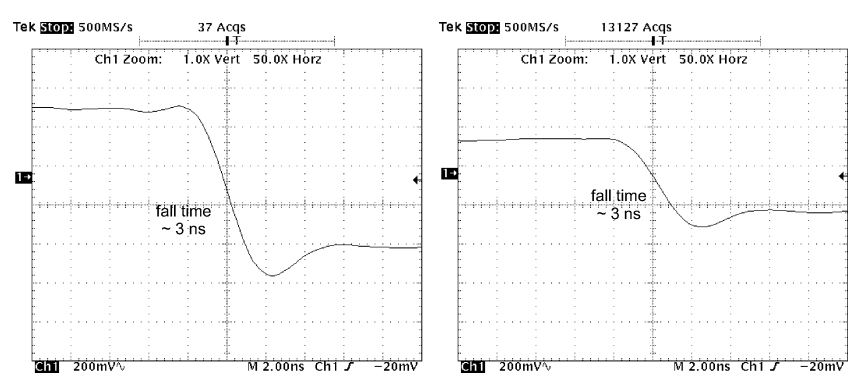

c)
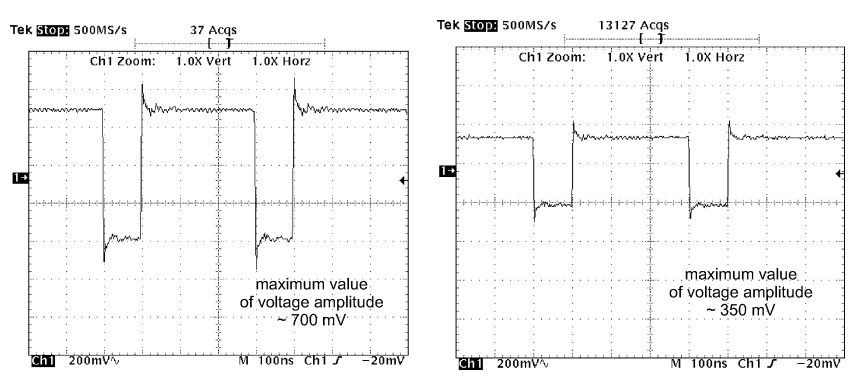

Fig. 5. Changes in signals measured in line G of VGA for two grey levels (white and grey 50\% Fig. 4)
DVI is characterised by a totally different method of coding colours. In this case, pixel with an applied colour is coded through combination " 0 " and " 1 ", retaining electric signal voltage parameters unchanged. This means that the signal levels of compromising emanations remain the same, regardless of colour intensity. This is also due to high sensitivity of decision systems on the receiving part or the monitor. Attempts to reduce amplitude voltage of a digital signal in the system cause pixels to be erroneously displayed or even a total monitor blackout.

Does reduction of colour intensity affect susceptibility of an IT system to infiltration? In order to answer this question relevant research was conducted, the results of which are presented below.

\section{Research results - quality of displayed images}

4.1. Change in intensity of font signs colour. The tests of signals of compromising emanations were conducted for different intensity degrees: $40 \%, 60 \%, 80 \%$ and $100 \%$ of black colour (Fig. 6). With the lowest of given intensity levels it is still possible to read textual data. With lower colour intensity levels the text becomes tedious to read and practically almost impossible.

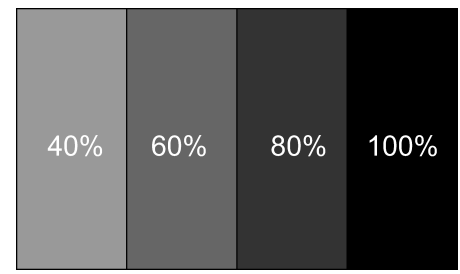

Fig. 6. Black colour intensity level for text tested

Graphics system of a computer operating in both VGA and DVI was tested. Based on the registered signals of compromising emanations images containing graphical elements, which originally were displayed with a different intensiveness degree were displayed through rastering. Graphical signs are letters written in font "Arial" corresponding to capital letters and ciphers. Displayed images are presented below.

Analysing above images we can notice that there is a strict relation between character colour intensity of the written text and registered signal levels of compromising emanations for VGA. Lower intensity level means that graphical signs contained in the image are harder to recognise. This is an extremely important feature as regards the possibility of applying the solution in protection of non-public information.

Conducting visual analysis of images from Figs. 7 and 8 we can conclude that DVI signal voltage amplitude is resistant to changes in colour intensity of graphical elements. This confirms that the colour displayed on the monitor is coded not by voltage amplitude, but a combination " 0 " and " 1 " in a 10-bit sequence for every pixel. 
I. Kubiak

a)

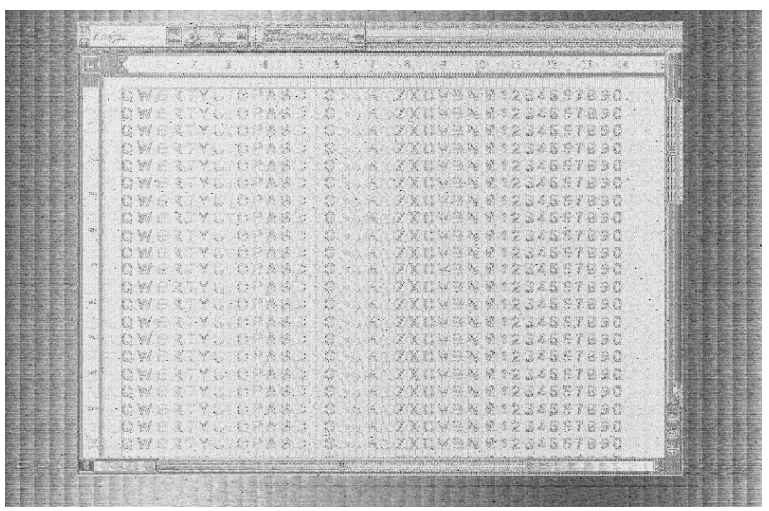

b)

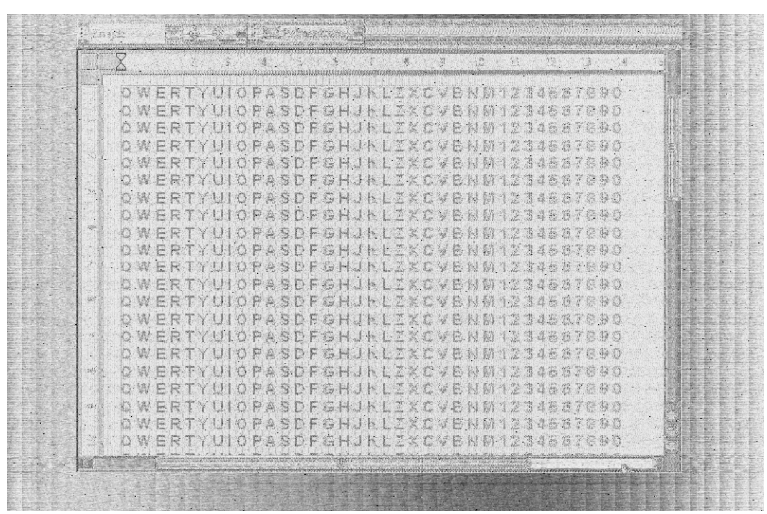

c)

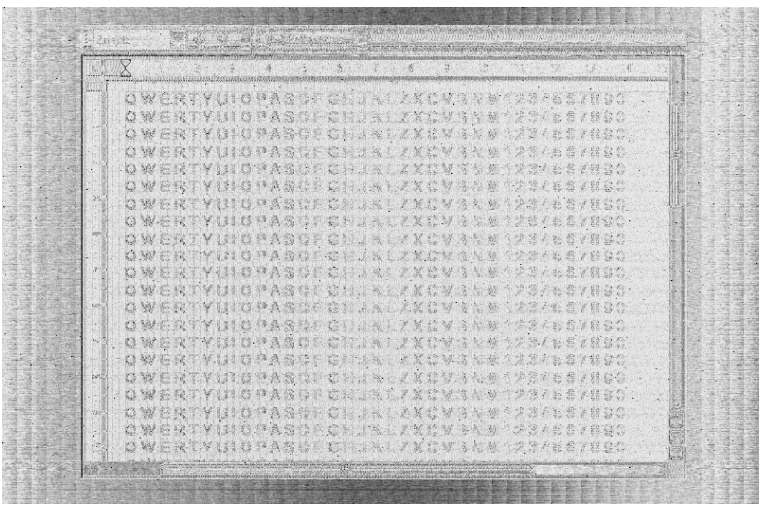

d)

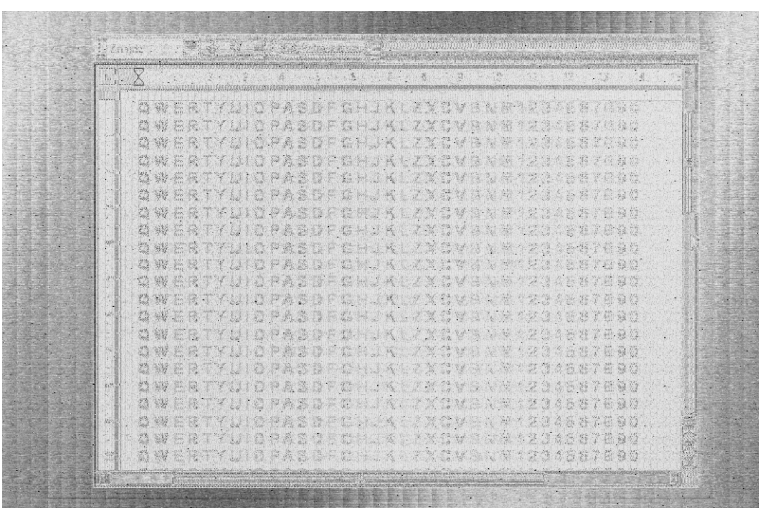

Fig. 7. Images (inversions of images) displayed through rastering from signals of compromising emanations measured at frequency of $350 \mathrm{MHz}$ for different intensity levels of black colour for written text - DVI: a) $40 \%$, b) $60 \%$, c) $80 \%$, d) $100 \%$ a)

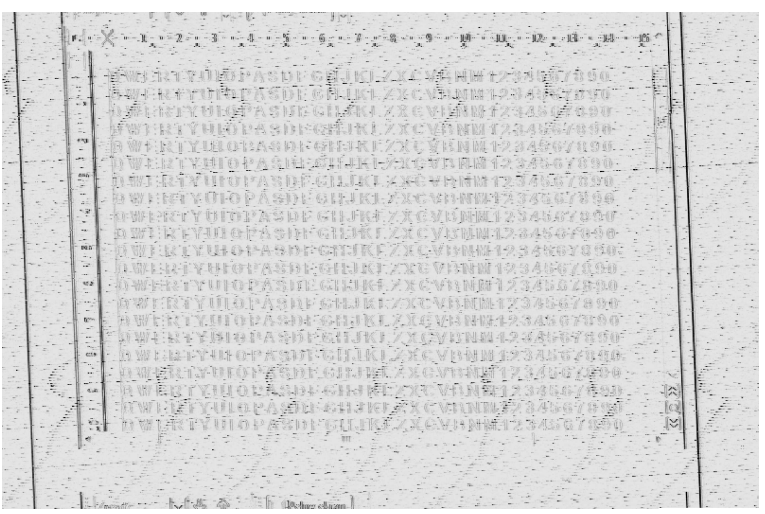

b)

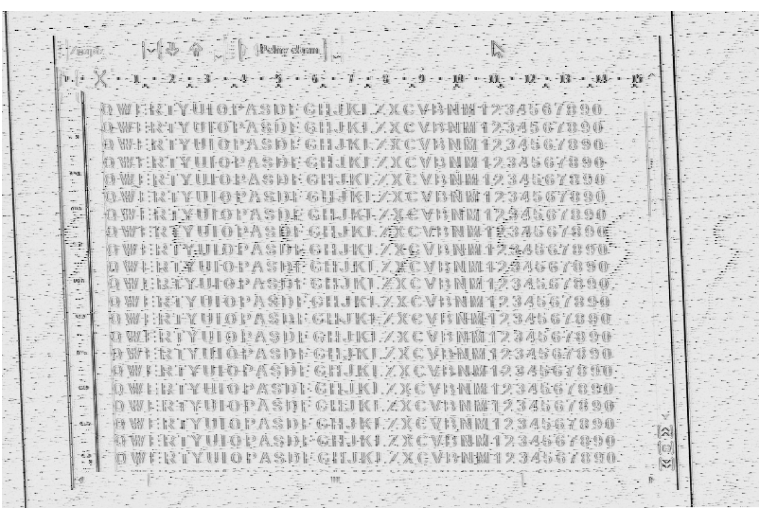

c)

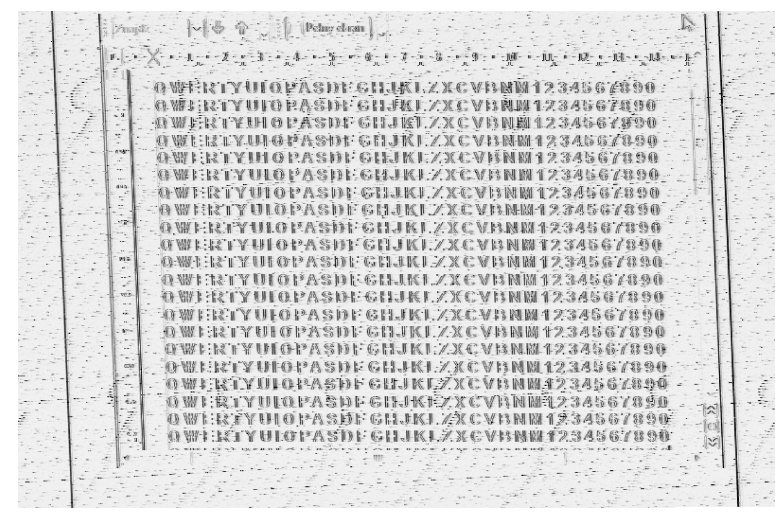

d)

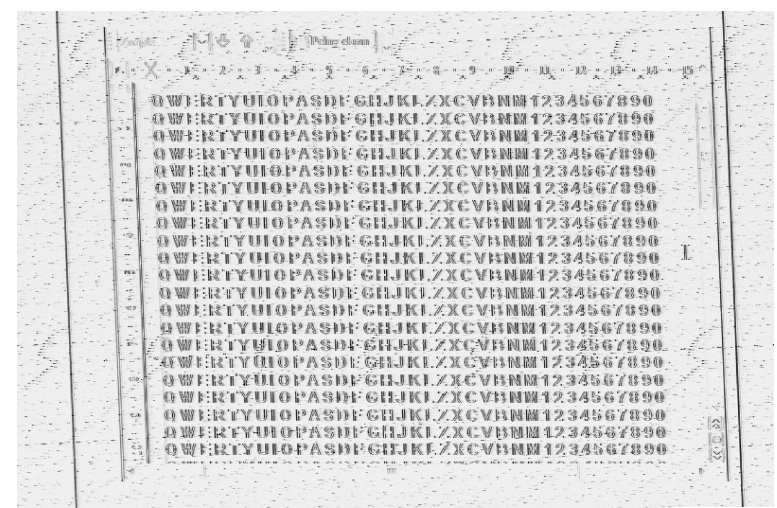

Fig. 8. Images (inversions of images) displayed through rastering from signals of compromising emanations measured at frequency of $70 \mathrm{MHz}$ for different intensity levels of black colour for written text - DVI: a) $40 \%$, b) $60 \%$, c) $80 \%$, d) $100 \%$ 
Video signal level (colour intensity) and effectiveness of electromagnetic infiltration

4.2. Change in intensity of font signs background. Reading a text written on the backgrounds with a different intensity degree of black colour we have an impression that text is more legible and the sight is not as tired as in the case of a very high contrast (white background or zero intensity of black colour). Moreover, considering the tests results obtained by Professor Bror Zachrisson tests which affect signal level of emissions correlated with processed information.

The tests of signals of compromising emanations for VGA (for DVI coding of different colour intensity degree does not affect video signal level and thus quality of displayed images) were conducted for different background intensity degrees: $20 \%, 30 \%, 40 \%, 60 \%$ and $80 \%$ of black colour (Fig. 9).

a)

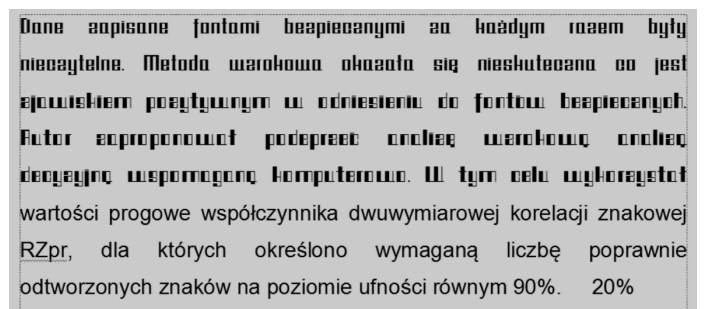

b)

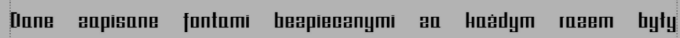

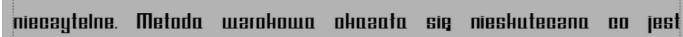

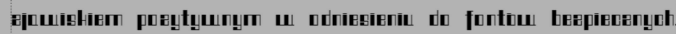
Futor enproponount porfepres nolieg uernhoug nolieg

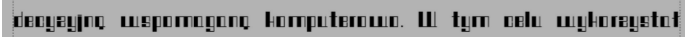
wartości progowe współczynnika dwuwymiarowej korelacji znakowej RZpr, dla których określono wymaganą liczbę poprawnie odtworzonych znaków na poziomie ufności równym $90 \%$. 30\%

c)

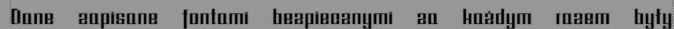

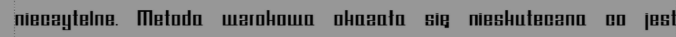

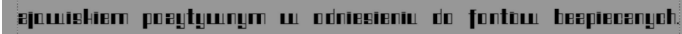

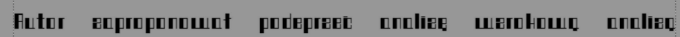

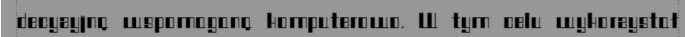
wartości progowe współczynnika dwuwymiarowej korelacji znakowej RZpr, dla których określono wymaganą liczbę poprawnie odtworzonych znaków na poziomie ufności równym 90\%. $\quad 40 \%$

d)

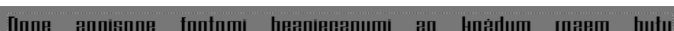

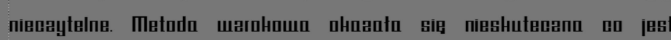

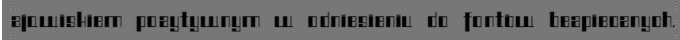
Futor enproponount porieprese molieg uerohoug nolieg

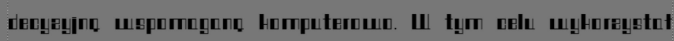
wartości progowe współczynnika dwuwymiarowej korelacji znakowej RZpr, dla których określono wymaganą liczbę poprawnie odtworzonych znaków na poziomie ufności równym $90 \%$. 60\%

e)

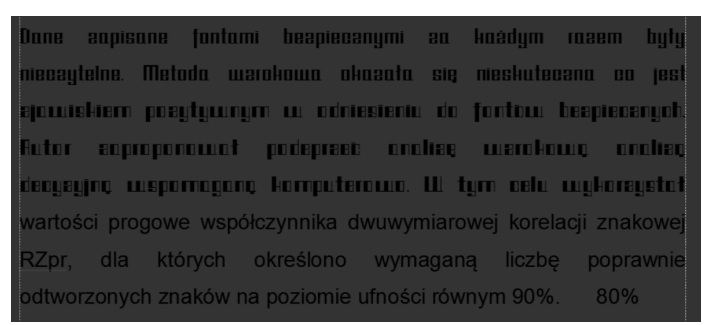

Fig. 9. Exemplary images containing texts written in safe and traditional fonts on backgrounds with different intensity level of black colour: a) $20 \%$, b) $30 \%$, c) $40 \%$, d) $60 \%$ and e) $80 \%$
With $60 \%$ it is still possible to read textual data without considerable problems. With $80 \%$ background intensity of black colour it may already be difficult to read textual data, and longer work on such text already becomes tedious. Nevertheless, the results in form of images which were obtained from signals of compromising emanations at frequency of $712 \mathrm{MHz}$ are satisfactory (Fig. 10).

a)

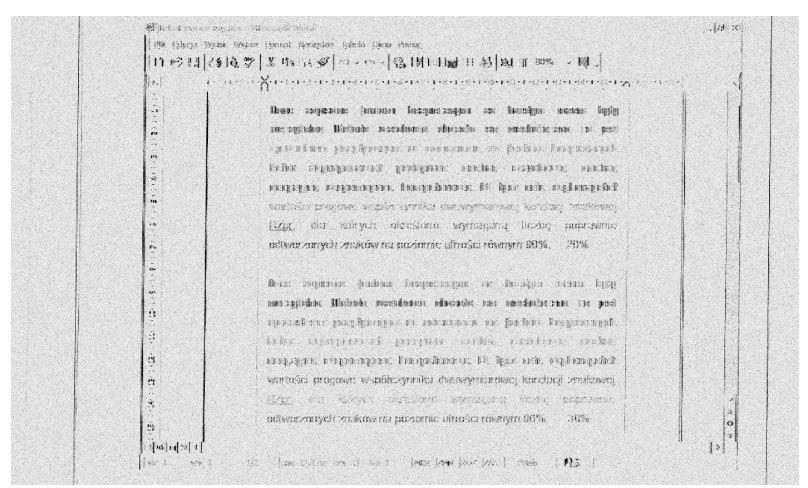

b)

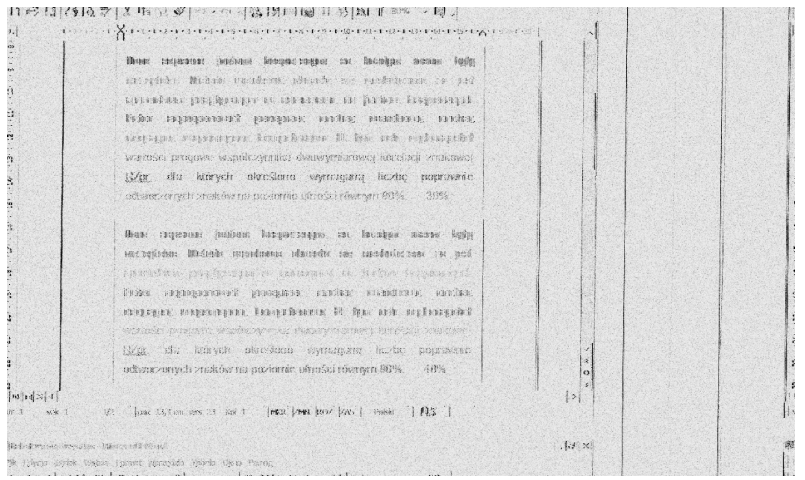

c)

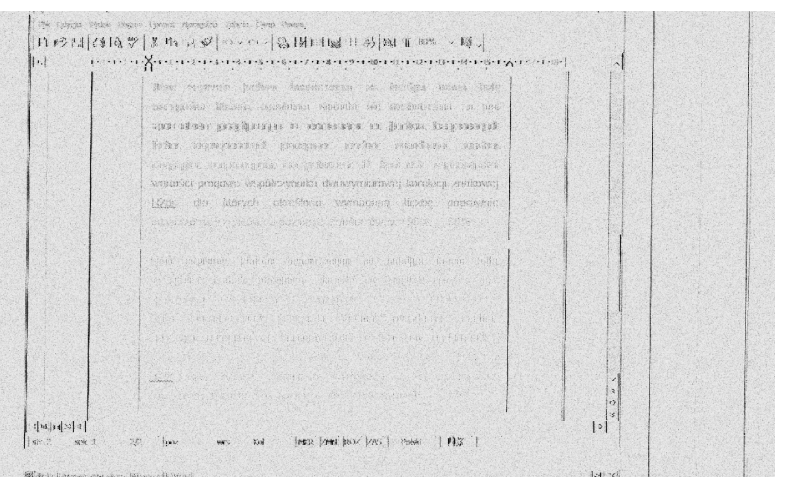

Fig. 10. Images obtained through rastering from signals of compromising emanations for different background intensity degree of graphical signs - image inversions

Every image contained two paragraphs of text written in three different fonts. Reading from top to bottom it was font: "Safe Symmetrical", "Safe Unsymmetrical" and "Arial". The first paragraph of image text from Fig. 10a was written on the background of $20 \%$ intensity, the second $-30 \%$ intensity. Figure 10b are from top to bottom: $30 \%$ intensity and $40 \%$ intensity, and Fig. 10c: $60 \%$ intensity and $80 \%$ intensity. 
I. Kubiak

Undoubtedly, background change of graphical signs affects reduction in differences between sign and background amplitude. Not without reason, it also affects signal level of compromising emanations. Notice that for a background with $60 \%$ colour intensity distinctiveness of signs and thus their recognisability is very difficult. Some of the signs of font "Arial" are still tolerable, whereas the signs written in safe fonts are illegible and unrecognisable. Besides, texts of font "Safe Symmetrical" and "Safe Unsymmetrical" are traceable as darker lines allowing only for identifying their presence in the image.

\section{Endeavours of quality improvement of displayed images}

The above examples of displayed images were obtained for conditions close to ideal. There are no other significant impairments or noises that could negatively affect the outlines of graphical elements present in images. In actual conditions we should expect the present graphical signs to be partially blurred and to have poor contrast, which in the case of reduction of original video signal level will make the possibility of visual analysis even harder.

Images shown in Fig. 8 were subject to processes of quality improvement which were aimed at extracting as many graphical details in displayed images as possible for every intensity degree of black colour. Method for thresholding of amplitude values of image pixels, extending histogram of pixel amplitude values and logical filtration were used. The results are presented below.

\subsection{Change in intensity of graphical signs colour. Thresh-} olding of image pixels amplitude values. The method requires determining thresholds (upper $P_{G}$ and lower $P_{D}$ ) of amplitude values $x(n, m)$ of image pixels (with coordinates $n$ and $m$ ) for which according to the relation:

$$
y(n, m)=\left\{\begin{array}{lll}
0 & \text { when } & x(n, m)>P_{G}, \\
255 & \text { when } & x(n, m) \geq P_{D}
\end{array}\right.
$$

new values of image pixels amplitudes $y(n, m)$ are adopted. The impairments of the image in form of pixels with considerable amplitude values whose values are reduced to zero (Fig. 11).

Filtration with horizontal logical filter. Conducted analyses and tests of filtration with horizontal logical filter showed that in the case of VGA the most effective is a horizontal filter (Fig. 12). It is directly related to the shape of graphical signs in displayed images. Graphical elements are marked by vertical and horizontal edges of original signs. Operating principle of the filter is described by the relation:

$$
y(n, m)=\left\{\begin{array}{c}
255 \quad \text { when } \\
|x(n, m-1)-x(n, m+1)|>B, \\
x(n, m) \text { when } \\
|x(n, m-1)-x(n, m+1)| \leq B,
\end{array}\right.
$$

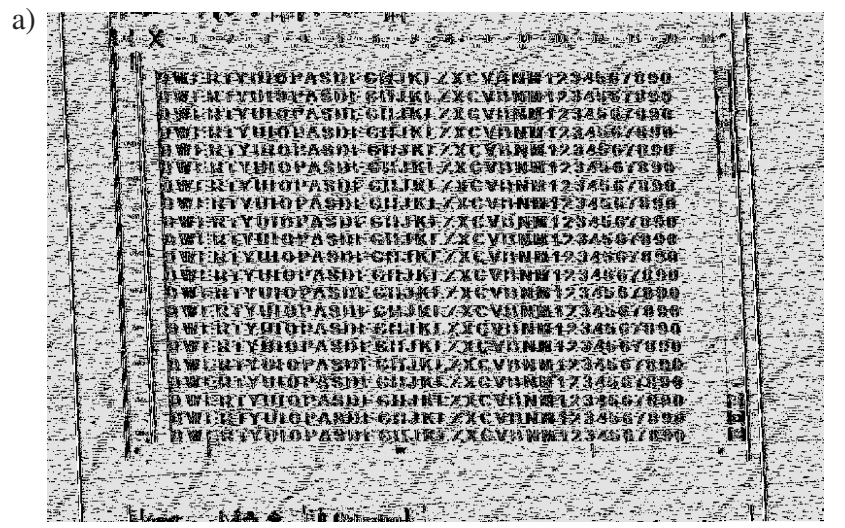

b)

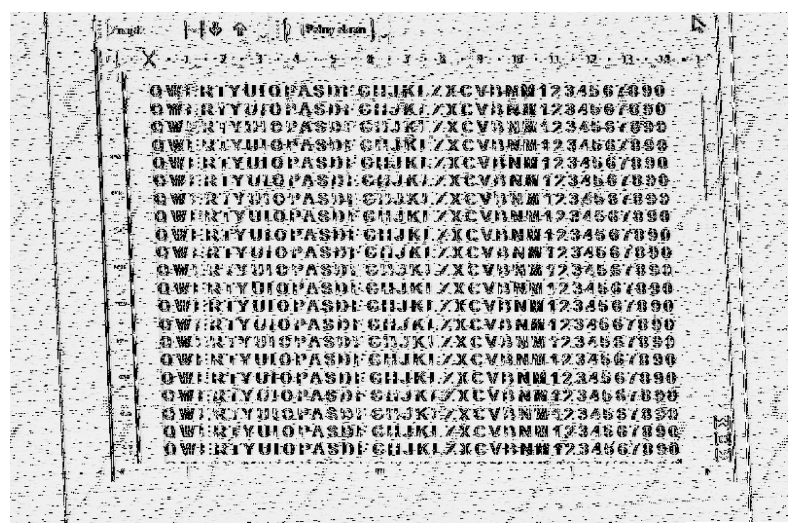

Fig. 11. Thresholding of image pixel amplitude values a) from Fig. 8a $\left(P_{G}=140, P_{D}=135\right)$ and b) from Fig. $8 \mathrm{c}\left(P_{G}=200, P_{D}=60\right)$
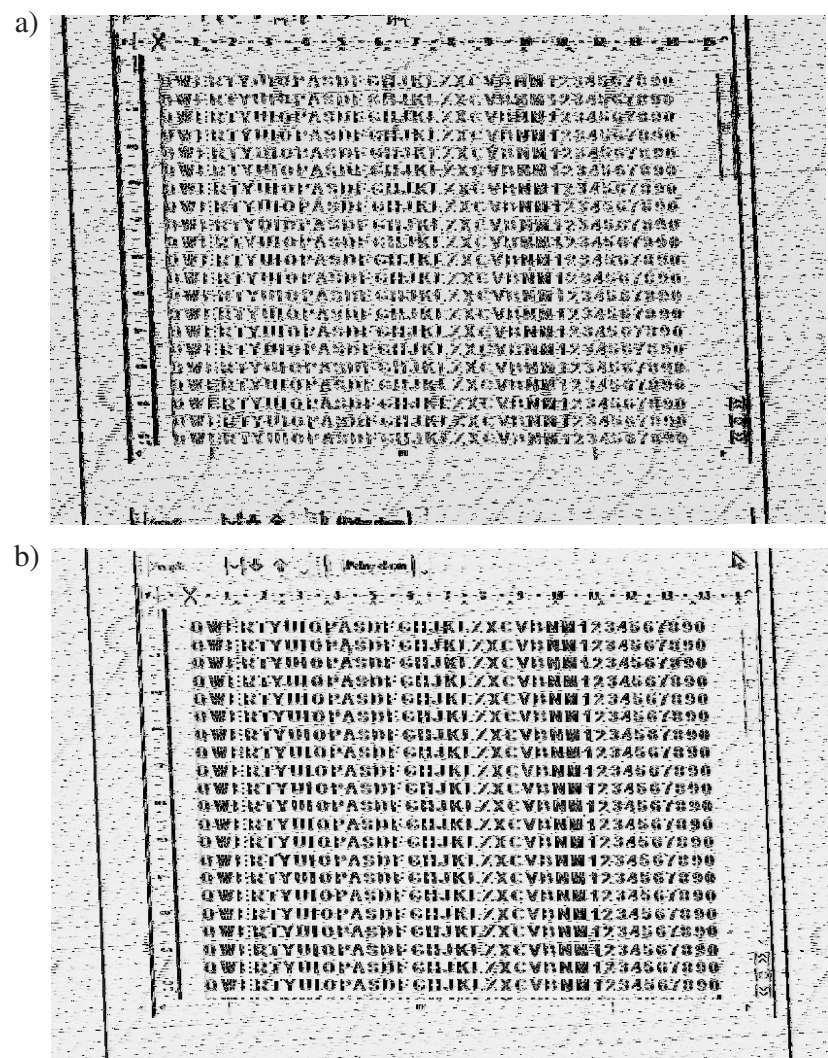

Fig. 12. Filtration with horizontal logical filter for applied values of decision threshold, a) image from Fig. $8 \mathrm{a}, B=10$, b) image from Fig. $8 \mathrm{c}, B=35$ 
Video signal level (colour intensity) and effectiveness of electromagnetic infiltration

where $n$ - image line number; $m$ - image column number; $x(n, m)$ - pixel amplitude value of analysed image with coordinates $n$ and $m ; x(n, m)$ - pixel amplitude value of modified image with coordinates $n$ and $m ; B$-decision threshold value of horizontal filter; $x(n, m-1)$ - pixel amplitude with coordinates $n$ and $(m-1)$ of analysed image; $x(n, m+1)-$ pixel amplitude with coordinates $n$ and $(m+1)$ of analysed image. Extension of selected fragment of image pixel amplitudes values. In the method it is necessary to provide two threshold values: lower $H_{p r}^{D}$ and upper $H_{p r}^{G}$. threshold. The thus determined range is subject to extension. Some of information contained in pixels whose amplitude values are not included in the range indicated by $H_{p r}^{D}$ and $H_{p r}^{G}$ is lost. However, these are pixel amplitudes values which are decisive for the image background (Fig. 13).

a)

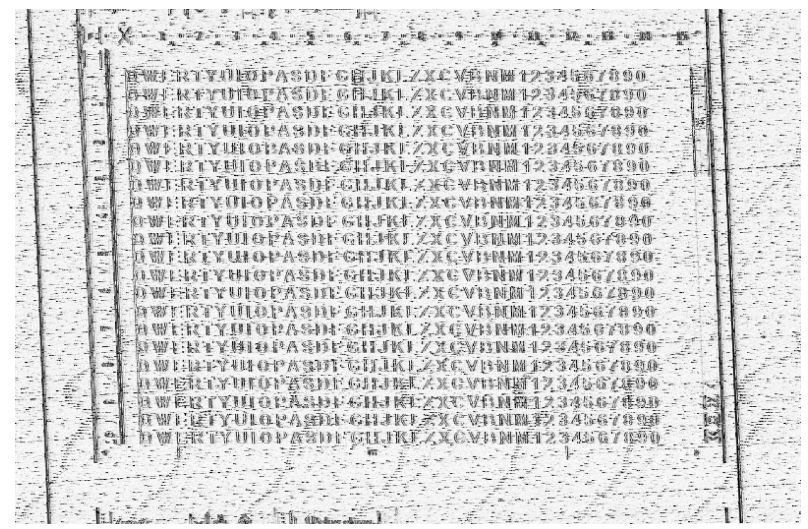

b)

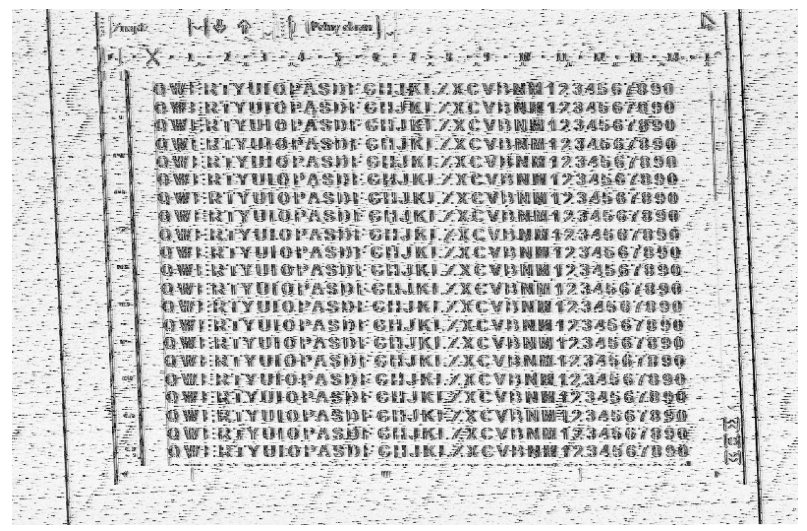

Fig. 13. Extension of selected fragment of pixel amplitudes values histogram through determining lower and upper threshold of histogram, a) image from Fig. $8 \mathrm{a}, H_{p r}^{D}=25, H_{p r}^{G}=90$, b) image from Fig. 8c, $H_{p r}^{D}=15, H_{p r}^{G}=120$

5.2. Change in colour intensity of graphical signs background. Addition of images. Addition of images allows for elimination of noise from analysed image by approximating the values of its amplitudes. Therefore, graphical elements that we want to identify become more visible and distinct. To addition of images were subject images for which written text was located on the background with a different intensity degree of black colour (Fig. 14).

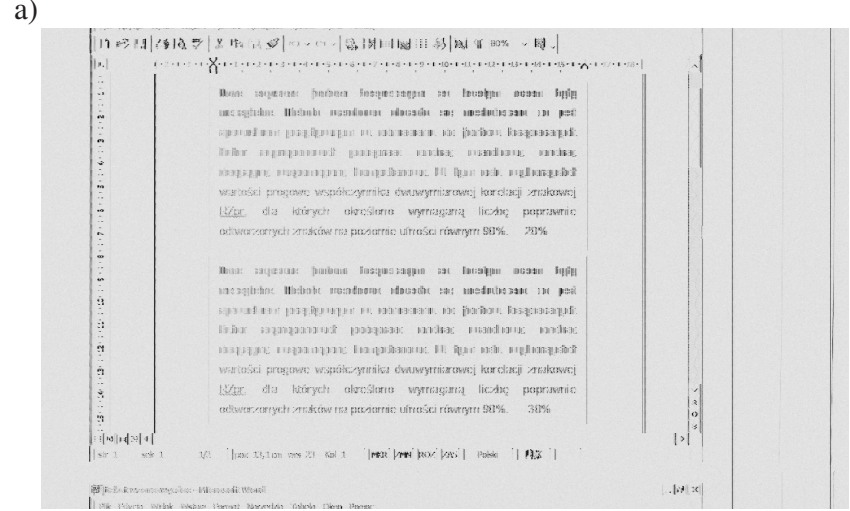

b)

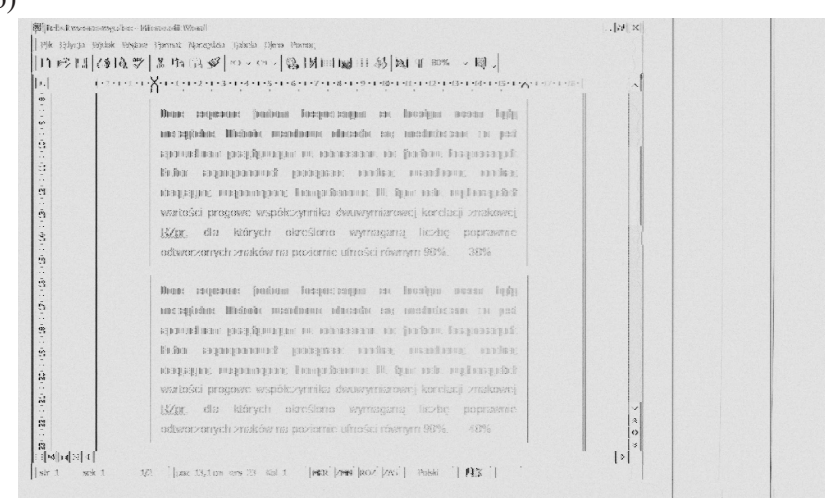

c)

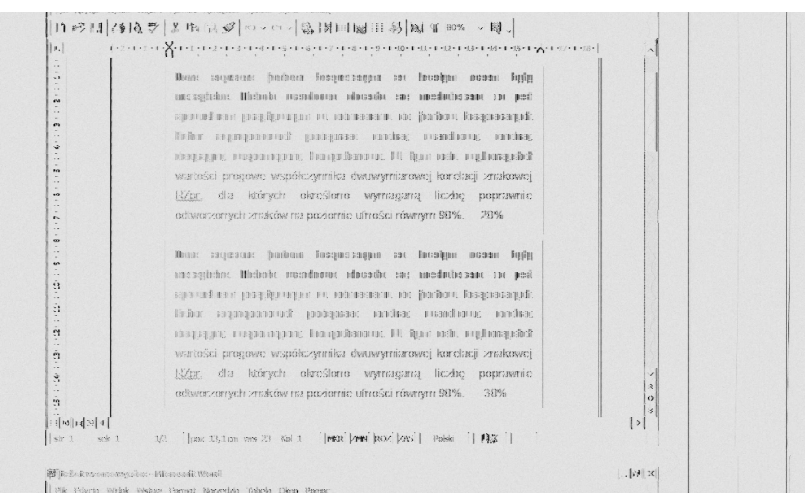

Fig. 14. Influence of images addition on visibility of graphical signs that we want to identify in displayed images, a) 20-time image addition from Fig. 10a, b) 30-time image addition from Fig. 10b, c) 30time image addition from Fig. $10 \mathrm{c}-$ inversions of images

Addition of images and thresholding of image pixel amplitudes values. Thresholding of image pixel amplitudes values is done according to the relation:

$$
y(n, m)=\left\{\begin{array}{lll}
255 & \text { when } & x(n, m) \geq P_{g} \\
0 & \text { when } & x(n, m) \leq P_{d}
\end{array}\right.
$$

This allows for increasing image dynamics by reducing noise pixel amplitudes values to minimum (0) and maximising pixel amplitudes values (255) which may be decisive for the shape of the signs we want to identify. The influence of thresholding used is shown below (Fig. 15). 
a)

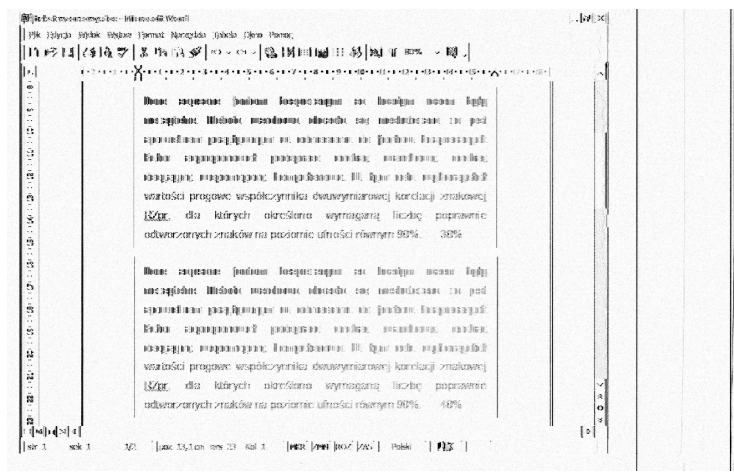

b)

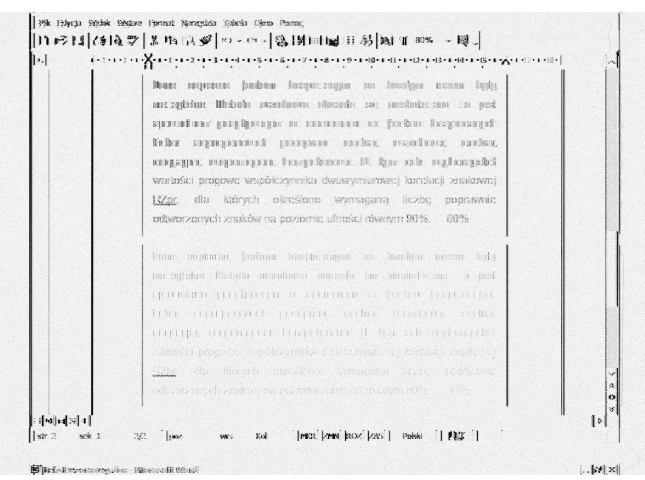

Fig. 15. Images addition and thresholding of image pixel amplitudes values for image presented in: a) Fig. 12b, b) Fig. 12c - inversions of images

\section{A result analysis - VGA and DVI graphic standards security}

The test results concern searching for solutions that counter electromagnetic infiltration. Solutions used nowadays involve design modifications to commercial devices. These, however, are very expensive. Attempts to find new and less expensive solutions, which will also be efficient, are being searched for. One of the methods is the possibility to control the graphic path of computer monitor with the voltage of a useful signal. Graphic path is the main source of revealing emissions for both standard analogue VGA (despite its age it is still very popular with TEMPEST-class computers) and digital DVI. The control is realised by changing contrast between data displayed on the computer monitor and the background. As shown in test results, the change in contrast between the above-mentioned elements for the DVI graphic standard does not force changes in useful signal voltages. In this case, the information about colours is coded in the bit structure of the signal. However, changes in the number of logical passes from " 1 " to "0" and back occur.

The results obtained in the form of images restored from registered revealing emission signals show that the effectiveness of emission sources (including revealing emissions) depends on the amplitude of voltage of signals, which stimulate the source. For the VGA standard, the efficiency of the source can be adjusted by the differences in signal voltage amplitudes responsible for displaying graphic characters and background, on which they appear. Smaller differences result in lower effectiveness of the source of revealing emissions. This is shown by combinations of colours of characters and background in the area of shades of grey (Figs. 16 and 17).

a)

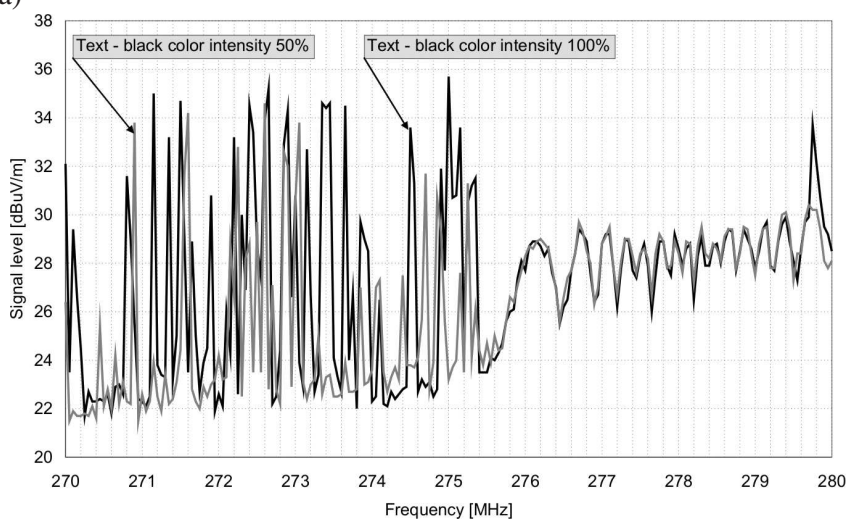

b)

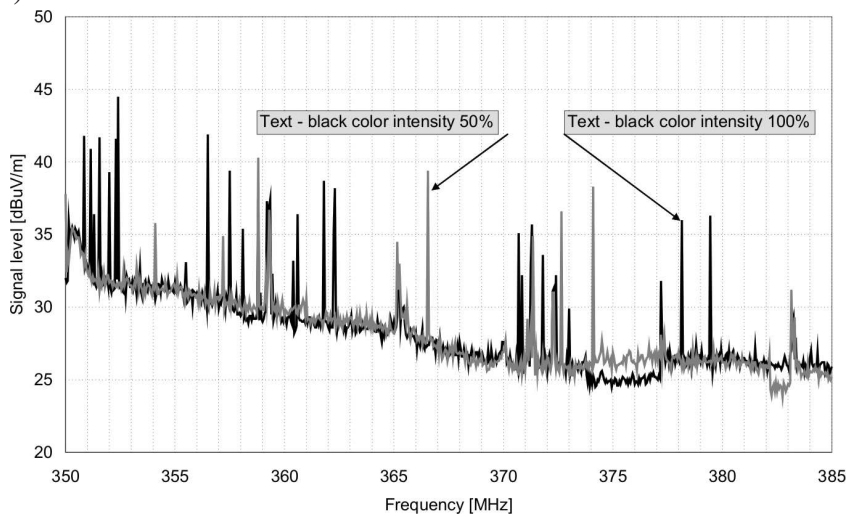

Fig. 16. The radiated emission level from computer, VGA video signal standard, for two cases: the displayed image in the form of normal text in black color (100\% intensity) on the white background and the image in the form of normal text in black color (50\% intensity) on the white background (measuring distance $d=1 \mathrm{~m}$ ), for two range frequencies: a) 270-280 MHz and b) $350-385 \mathrm{MHz}$

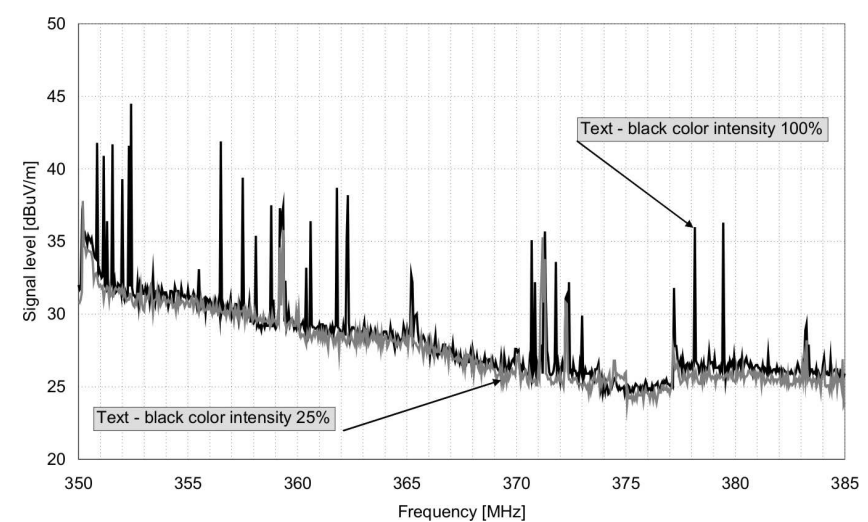

Fig. 17. The radiated emission level from computer, VGA video signal standard, the displayed image in the form of normal text in black color (100\% intensity) on the white background and the image in the form of normal text in black color (25\% intensity) on the white background (measuring distance $d=1 \mathrm{~m}$ ), the range frequency 350-385 MHz

For the DVI standard, the colours are coded with electric signal bit structure, not with its value of voltage am- 
Video signal level (colour intensity) and effectiveness of electromagnetic infiltration

plitudes, which is constant. The result is that the analogue VGA standard, as a revealing emission source, can be modelled by changing colour intensity between graphic characters and background. In images restored from revealing emission signals, with decreased contrast, the differences between the background and the useful information fade away. This phenomenon does not occur for the DVI standard. Regardless of the differences between the background and graphic characters on the background, the restored images are of a similar quality. At the same time, the characters are characterised by a high level of perception. It should also be noted that the digital DVI standard is not an electromagnetically secure standard, as it is often suggested.

The restored graphic characters, as opposed to the VGA standard, for which the restored graphic characters are identified only by vertical and diagonal edges, are filled. This results directly from the bit structure of the useful signal. Thus, the revealing emission signal of the DVI standard has more distinctive features, making it more resistant to disturbances in the Information Penetration Canal. a)

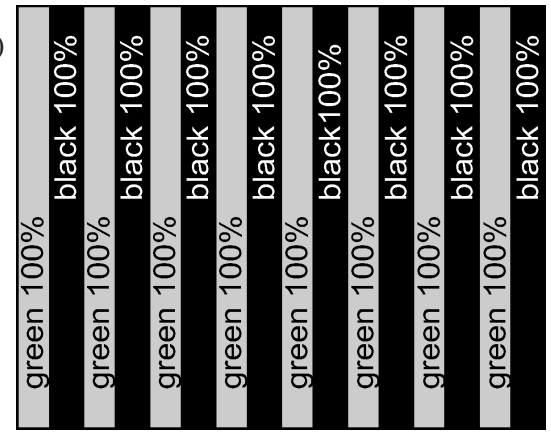

b)

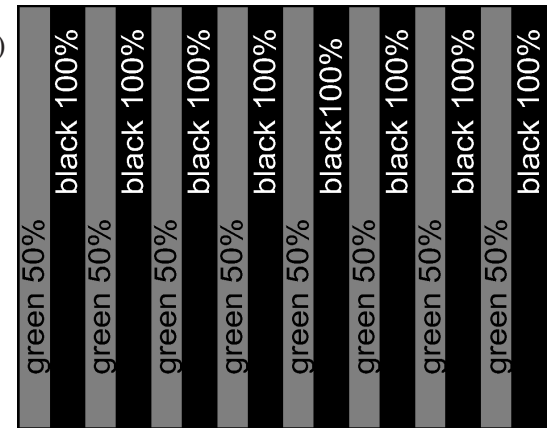

c)

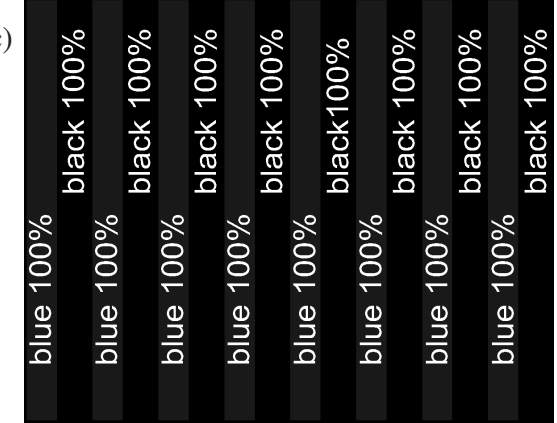

Fig. 18. The display images on the monitor during the time parameter tests of the VGA standard useful signals: a) light green color (50\% intensity), b) dark green color (100\% intensity), c) blue color (100\% intensity) a)

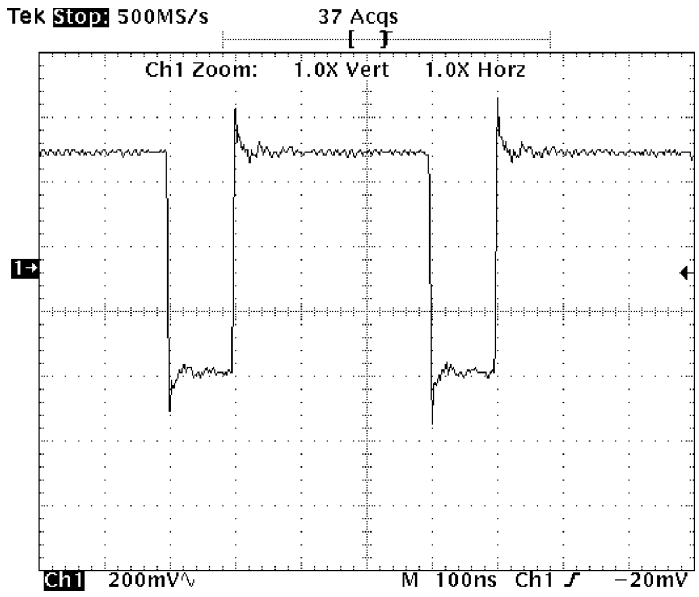

b) Tek Stop: 500Ms/s $\quad 13127$ Acqs

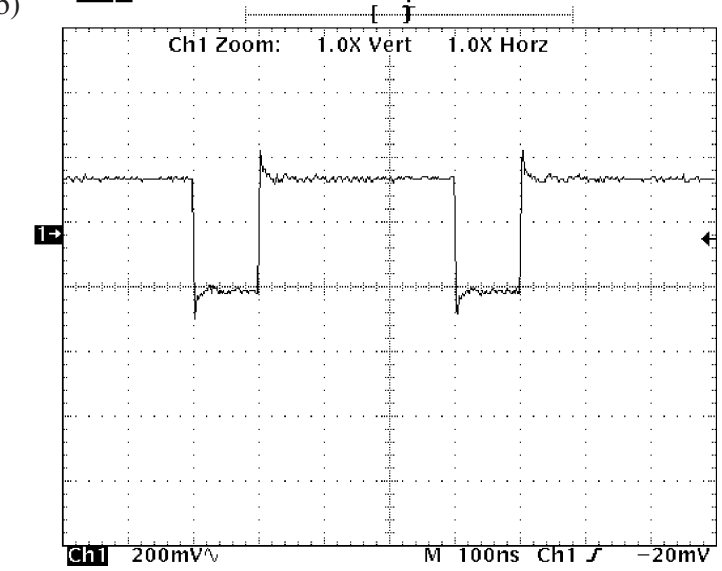

c)

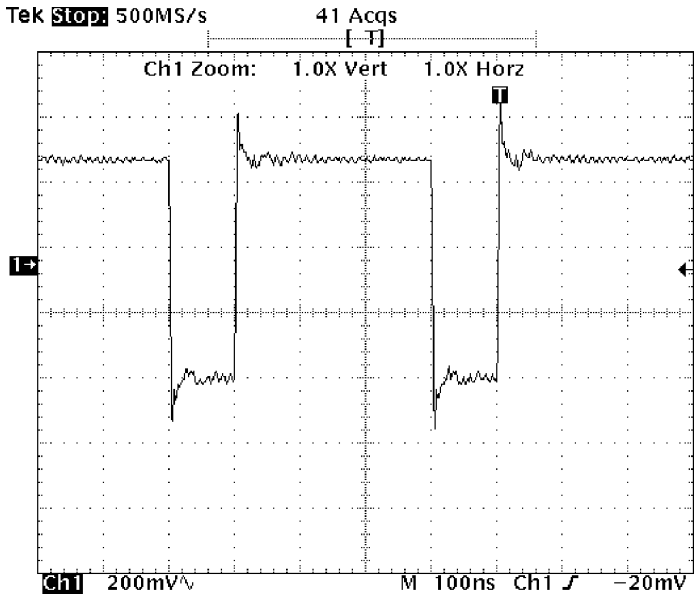

Fig. 19. The measure signals in time domain in the lines $G(a, b)$ and $\mathrm{B}$ (c) of the VGA standard for two green colors ( $\mathrm{a}-50 \%$ intensity,

b $-100 \%$ intensity) and c) for blue color (100\% intensity)

As it has been mentioned, the conducted research was related to the cases of the combined use of shades of grey. Similar conclusions concern situations when other colours are used for the creation of a graphic. The maximum difference of the useful signal voltages (white and black) for the VGA standard is approximately $700 \mathrm{mV}$. Each smaller difference decreases the efficiency of the source of unwanted signals emission. Examples of useful signal parameters for three cases of different colours (green - 100\% intensity, green $-50 \%$ intensity, blue $-100 \%$ intensity, Fig. 18) are shown in Fig. 19. 
In each case the width of the coloured line was 12 pixels, and for the black line -4 pixels. The following parameters of the displayed image were tested: resolution of $800 \times 600$ and refreshing frequency of $60 \mathrm{~Hz}$. As it may be seen, the appropriate level of electromagnetic protection may be achieved not only through the combination of shades of grey. Many other colours may also be used, e.g. 50\% intensity of green on a black background (100\% black intensity). Thus, the difference of signal voltage amplitudes is decreased to less than $400 \mathrm{mV}$.

The construction of the source of revealing emissions should also be considered. The source is not only an electric video signal, but it is the entire video path, with graphics card and transmission medium, i.e. the video cable. Various graphics cards and cables with various designs (internal structure) and lengths are more or less efficient radiation sources. This also impacts the range and the ability to register unwanted signals. Therefore, in addition to sensitive signal sources, which can be controlled (VGA standards) by changing the voltages of video signals, the effectiveness of the electromagnetic infiltration process highly depends on the effectiveness of electromagnetic energy radiation from the transmitter (video cable) and propagation features of revealing emission signals. It is, therefore, difficult to clearly identify an indicator that clearly describes the risk of electromagnetic infiltration and that would be right for different scenarios. Therefore, any device designed to process classified information is subject to tests and assessment of the effectiveness of the solutions to counter attack TEMPEST-type attacks.

Figures 20 and 21 show the course of electromagnetic emissions measured at a distance of $1 \mathrm{~m}$ from a complete source in various video cards and at different lengths of emission transmitter for the DVI standard.

Reduction in the level of useful signal voltage amplitudes impacts the measured levels of unwanted emissions (Fig. 16 and 17). In this case, it is important to determine the risk of electromagnetic infiltration, which involves the measure of image quality (level of readability) and the range of infiltration. For the assessment of the restored image two types of quality measures may be used: subjective and objective assessment. The subjective assessment requires laborious and time-consuming tests with the participation of many persons who evaluate the images. Images restored from revealing emission sources are most often images of very low quality. Their graphic elements must be extensively processed in order to be read. However, such image may be readable for some, but still worthless to others. According to users, the friendliest combinations (except the extreme ones: white background and black text) are shades of grey, with differences exceeding 50\%. This is confirmed by test results for readability for different coloured backgrounds and characters (Table 1), for which combinations other than white-black and white-dark blue reduce readability by about $20 \%$ and more, and become very tiring.

The appropriate selection of colours impacts the values of video signal amplitudes of the VGA standard. For the DVI standard the change of colours impacts the change of the zeroone structure of the video signal.

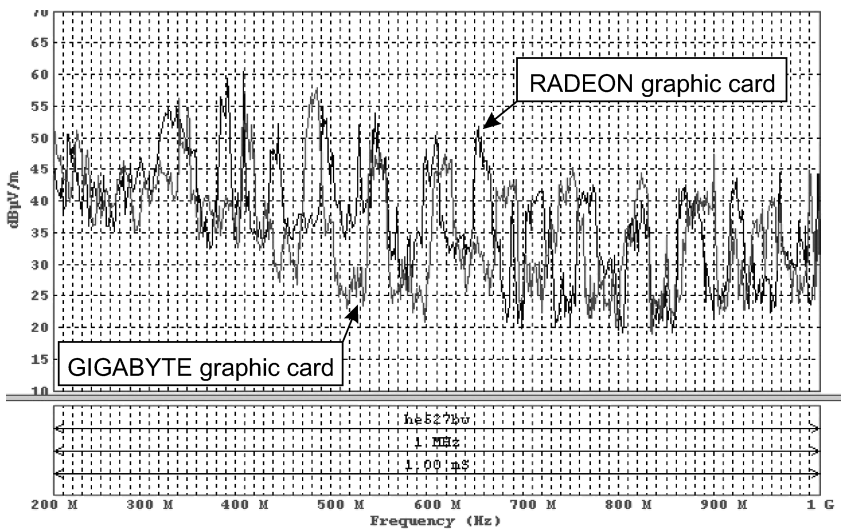

Fig. 20. The radiated emission level for constant length of DVI cable, range frequencies $200 \mathrm{MHz}-1 \mathrm{GHz}$, measure bandwidth $\mathrm{BW}=$ $1 \mathrm{MHz}$

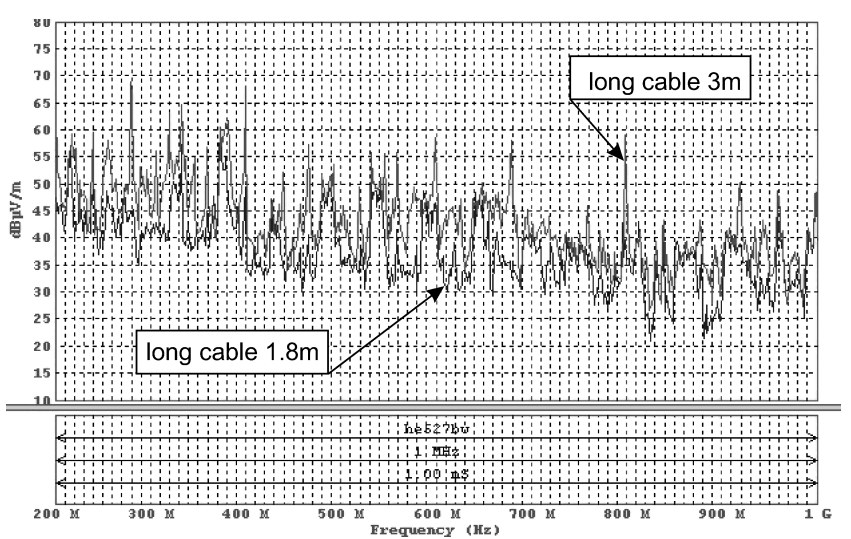

Fig. 21. The radiated emission level for two lengths of DVI cable and range frequencies $200 \mathrm{MHz} \div 1 \mathrm{GHz}$, measure bandwidth BW $=1 \mathrm{MHz}$

Table 1

Text legibility dipending on background and letters color after Ref. 23

\begin{tabular}{ccc}
\hline \hline The text color & The background color & The legibility [\%] \\
\hline Ciemnoniebieski & White & 100 \\
\hline Black & White & 100 \\
\hline Black & Yellow & 81 \\
\hline Yellow & Dark Blue & 70 \\
\hline Yellow & Dark Green & 67 \\
\hline White & Black & 64 \\
\hline Yellow & Dark Red & 60 \\
\hline Black & Red & 56 \\
\hline Yellow & Black & 56 \\
\hline Black & Light Green & 55 \\
\hline Black & Light Blue & 53 \\
\hline
\end{tabular}

The restored images evaluated by a group of observers can be classified using objective measurements independent of the human factor. The most often used measure of this type is the ration of useful signal energy to the energy of noise. The PSNR (Peak Signal to Noise Ratio) may be defined for a monochromatic image [22]:

$$
P S N R=10 \log \frac{N\left(2^{N_{b}}-1\right)^{2}}{\sum_{i} e_{i}^{2}}[\mathrm{~dB}],
$$


where $N$ - number of image points, $N_{b}$ - number of bits in the representation of image samples, $e_{i}$ - error of $i$ point.

The above ratio shows that the determination of an objective measure requires knowledge about the original image.

Due to the nature of the Information Penetration Canal, and thus form of the images reconstructed from revealing emission signals, a typical SNR is a more convenient measure of objective quality assessment:

$$
S N R=10 \log \frac{\sum_{i} f_{i}^{2}}{\sum_{i} e_{i}^{2}}[\mathrm{~dB}],
$$

where value of $i$ sample of image, $r_{i}$ - value of $i$ sample of reference image, $e_{i}=f_{i}-r_{i}$.

The determination of the range of information requires statistical tests which allow to determine:

- radio frequency ranges relevant in the context of the revealing emission signals propagation, arising as a result of information processing in teleinformatic devices of various types, in different operating modes;

- the intensity of the electromagnetic field associated with the propagation of revealing emission signals in designated frequency ranges at a given measuring distance (e.g. $1 \mathrm{~m})$;

- daily fluctuations in the level of environmental noise in designated frequency ranges, in certain environments, at different times of the year [25];

- attenuation of electromagnetic waves at predetermined frequency ranges associated with propagation in free space and offices [24].

However, the above-mentioned issues indicate the directions for further research and analyses.

\section{Summary}

The article presents solutions of masking non-public information by changing signal levels of the VGA and DVI video standards. Changes to the signal level made by different colour intensity of written text affected the quality of displayed images through rastering, using signals of compromising emanations. Conducted tests and analyses of compromising emanations signals measured from the graphics system operating in VGA and DVI showed there is no relation between the colour intensity degree and the quality of displayed image for DVI. In this case, colour intensity is not controlled by voltage amplitude value of a useful signal. This parameter is unchangeable. Changeable are combinations " 0 " and " 1 " in a 10-bit sequence for every pixel of displayed image.

VGA shows there is a complete relation between the colour intensity degree and voltage amplitude value of a useful signal, which translates directly to the measured signal levels of compromising emanations. This feature has a great influence on the quality of images displayed from registered signals of compromising emanations. We may search for a solution for electromagnetic information protection, whereby, one of its parts will be manipulation of colour intensity degree of characters and ciphers displayed on the monitor. Such solution concerning the possibilities of its use for DVI becomes pointless. In this case, it does not affect the signal levels of compromising emanations at all, and thus not the quality of displayed images. Colours in DVI are not coded using voltage, but through an appropriate combination " 0 " and " 1 " in bit structure of the signal.

\section{REFERENCES}

[1] I. Kubiak, "Digital processing methods of images and signals in electromagnetic infiltration process", Image Processing and Communications 18, DOI: 10.2478/v10248-012-0070-72014, 5-16 (2013).

[2] I. Kubiak, K. Grzesiak, S. Musial, and A. Przybysz, The Raster Generator in the Electromagnetic Infiltration Process, ISBN 978-83-62954-28-5, Publishing House of the Military University of Technology, Warsaw, 2012.

[3] I. Kubiak, "Identification of waveforms for electromagnetic fields on the basis of its measurements within a confined bandwidth of reception", PhD Thesis, Publishing House of the Military University of Technology, Warsaw, 2000.

[4] I. Kubiak, Analysis Methods and Digital Processing Images in Electromagnetic Infiltration Process, ISBN 978-83-62954-865, Publishing House of the Military University of Technology, Warsaw, 2013.

[5] I. Kubiak, "Possibilities of reconstruct of data text from unwanted signal emissions using char correlation method - standard DVI", Overview of Telecommunications and Telecommunication News 2-3, 46-50 (2014).

[6] I. Kubiak, "The computer font resistance to electromagnetic infiltration process", Przeglad Elektrotechniczny 90, 207-215 (2014).

[7] I. Kubiak, Computer Font Resistance to Electromagnetic Infiltration, ISBN 978-83-7938-018-3, Publishing House of the Military University of Technology, Warsaw, 2014.

[8] I. Kubiak, Computer Font Resistance to Electromagnetic Infiltration. The Research and Analysis Results, ISBN 978-837938-019-0, Publishing House of the Military University of Technology, Warsaw, 2014.

[9] N. Chandra and A. Goel, "A Technique for Image Encryption with Combination of Pixel Rearrangement Scheme Based on Sorting Group-Wise of RGB Values and Explosive Inter-Pixel Displacement", Int. J. Image, Graphics and Signal Processing 2/2012, DOI: 10.5815/ijigsp.2012.02.03, 16-22 (2012).

[10] B. Jalilian and A. Chalechale, "Persian sign language recognition using radial distance and Fourier transform", Int. J. Image, Graphics and Signal Processing 1/2014, DOI: 10.5815/ijigsp.2014.01.06, 40-46 (2014).

[11] N. Kulkarni, "Method for image segmentation of natural images", Int. J. Image, Graphics and Signal Processing 1/2012, DOI: 10.5815/ijigsp.2012.01.04, 28-34 (2012).

[12] R.G. Lyons, Understanding Digital Signal Processing, Amazon, New York, 2004.

[13] T. Zielinski, Digital Signal Processing, Communication and Transport Publisher, Warsaw, 2009.

[14] D.J. Park and K.N. Nam, "Multiresolution edge detection techniques", Pattern Recognition 28, 11 (1995).

[15] K. Pratt, Digital Image Processing, Wiley\& Sons, New York, 1978. 
[16] J.M. McCarthy, "The Pentagon worries that spies can see its computer screens, someone could watch what's on your VDT", The Wall Street J. 7, 8 (2000).

[17] R.L. Allen, Signal Analysis: Time, Frequency, Scale, and Structure, Springer, Berlin, 2004.

[18] H. Zeng, "Dual image processing algorithms and parameter optimization", Seventh Int. Conf. Natural Computation (ICNC) 2 , 946-950 (2011), ISSN 2157-9555.

[19] D.S. Sohi, Application to Enhance the Teaching and Understanding of Basic Image Processing Techniques, pp. 413-416, ISBN 0-7803-6312-4, Southeastcon, Naswille, 2000.

[20] S.K. Mitra, "Image processing using quadratic volterra filters", 5th Int. Conf. on Computers and Devices for Communication (CODEC) 2012, ISBN 978-1-4673-2619-3 (2012).

[21] K. Grzesiak and A. Przybysz, "Emission security of laser printers", MCC 2010: Military Communications and Information
Systems Conf. 1, CD-ROM (2010).

[22] M. Domański, Digital Image, Publishing House of WKŁ, Warsaw, 2010.

[23] S. Konz, R. Jackson, J. Knowles, and M. Verschelden, "Legible and attractive transparencies", Ergonomics Int. 88 (2), 549-551 (1988).

[24] I. Kubiak, K. Grzesiak, S. Musiał, and A. Przybysz, Electromagnetic Safety Information, Publishing House of Military University of Technology ISBN 978-83-61486-32-9, Warsaw, 2009.

[25] I. Kubiak, Results of Measurements and Analyses of Electromagnetic Compatibility of the TETRA System of the Warsaw Police Headquarters in Comparison with Other Systems in Warsaw and Its Vicinity, Military Communication Institute, Warsaw, 2000. 